\title{
PENERAPAN E-COMMERCE GUNA MENINGKATKAN PENJUALAN HEYHO GROUP INDONESIA
}

\author{
Muhammad Dinda Saputra ${ }^{1)}$, Hestya Patrie ${ }^{2)}$ \\ ${ }^{1}$ Sistem Informasi, Fakultas Teknologi Informasi, Universitas Budi Luhur \\ ${ }^{1,2} \mathrm{Jl}$. Raya Ciledug, Petukangan Utara, Kebayoran Lama, Jakarta Selatan 12260 \\ E-mail : 1412501536@student.budiluhur ${ }^{1}$, hestya.patrie@budiluhur.ac.id ${ }^{2)}$
}

\begin{abstract}
Abstrak
Heyho Group Indonesia adalah satu tempat bisnis yang memproduksi fashion masa kini pada kalangan remaja untuk itu Heyho Group Indonesia mempunyai pemikiran bisnis yang sangat luas untuk memperkenalkan produk Brand dalam negri, seiring berkembangnya jaman peminat fashion semakin meningkat. Pada umumnya usaha dengan konsep pejualan fashion mengutamakan kebutuhan untuk anak-anak muda, pelajar dan mahasiswa. penulis melakukan analisa mengenai sistem penjualan tersebut, dimana sistem yang sedang berjalan pada Heyho Group Indonesia belum menggunakan teknologi berbasis web, seperti melakukan penjualan produk fashion yang terdapat pada brand dan pembuatan laporan bulanan. Begitupun dengan pengolahan data yang dihasilkan dari transaksi yang terjadi masih menggunakan tulisan tangan, sehingga memungkinkan terjadinya kesalahan atau masalah seperti kekeliruan dalam penulisan dan perhitungan. Dengan adanya teknologi yang berkembang pesat saat ini, sangat mungkin untuk mendukung bisnis menjadi lebih berkembang dan maju. Hal tersebut menjadi peluang untuk menangani masalah yang terjadi pada Heyho Group Indonesia . Dengan merancang sistem penjual berbasis web dengan memanfaatkan teknologi, diharapkan mampu memberikan dampak positif bagi Heyho Group Indonesia Sehingga kegiatan penjualan produk menjadi lancar serta mampu bertahan dan bersaing dengan bisnis serupa yang ada saat ini. Penulis mengimplementasikan dengan menggunakan Microsoft Visio 2013 dan menggunakan database MySQL.
\end{abstract}

Kata kunci: E-commerce, Penjualan Fahion Brand, Berbasis Web

\section{PENDAHULUAN}

\subsection{Latar Belakang}

E-Commerce (Elektronic Comerce) atau bisa di sebut dengan perdagangan elektronik pembelian adalah pembelian, penjualan pemasaran barang dan jasa melalui internet dan jaringan komputer. Seluruh komponen yang ada dalam perdagangan diaplikasikan ke dalam e-commerce seperti customer service, layanan produk, cara pembayaran dan cara promosi. Perkembangan internet semakin maju merupakan salah satu pendorong berkembangnya $e$ commerce, Internet merupakan salah satu jaringan global yang menghubungkan jaringan komputer diseluruh dunia, sehingga komunikasi dan interaksi antar satu instansi dengan konsumen.

Heyho Group Indonesia adalah satu tempat bisnis yang memproduksi fashion masa kini pada kalangan remaja untuk itu Heyho Group Indonesia mempunyai pemikiran bisnis yang sangat luas untuk memperkenalkan produk Brand dalam negri, seiring berkembangnya jaman peminat fashion semakin meningkat. Pada umumnya usaha dengan konsep pejualan fashion mengutamakan kebutuhan untuk anak-anak muda, pelajar dan mahasiswa.

1) Visi (Rencana yang akan dicapai suatu perusahaan)

a. Menjadi sebuah toko Fashion yang memberikan kepuasan kepada pelangganya dengan cara memberikan pelayanan dan kualitas produk yang baik.

b. Membuat pelanggan mencintai produk dalam negri hasil karya anak bangsa

2) Misi (Kegiatan yang mengarahkan perusahaan pada tujuan yang menjadi impiam perusahaan)

a. Menawarkan produk yang berkualitas yang tidak jauh beda dari Brands Fahion luar negri.

b. Memberikan pelayanan yang baik kepada konsumen sehingga kebanyakan dari mereka akan menjadi pelanggan tetap.

Berdasarkan hasil yang menguntungkan yang dilakukan pada Heyho Group Indonesia merupakan sebuah usaha fashion dan semakin berkembangnya serta semakin tingginya kebutuhan masyarakat terhadap pelayanan yang berhubungan dengan kebutuhan fashion, makasaya sebagai penulis memutuskan untuk membangun E-Commerceyang dimana produknya berdasarkan update-update fashion masa kini dan juga akan menyediakan layanan pemesanan untuk para konsumen (order) sehingga konsumen bisa menikmati hasil pesanannya sesuai keinginan.

Kehadiran e-commerce sebagai media transaksi baru ini tentunya menguntungkan banyak pihak, baik pihak konsumen, maupun pihak produsen dan penjual. Dengan menggunakan internet, proses 
perniagaan dapat dilakukan dengan menghemat biaya dan waktu.

Penulis mencoba untuk merancang $e$ commerce dengan memanfaatkan teknologi internet dalam penjualan dan proses bisnisnya sehingga dapat diakses kapan saja dan dimana saja oleh pelanggan.

Rancangan ini juga harus interaktif sehingga pelanggan dapat berperan secara aktif dalam proses bisnis penjualannya. Untuk itu, pada penelitian ini penulis memberikan judul "Pembangunan ECommerce Pada Heyho Group Indonesia”.

\subsection{Permasalahan}

Permasalahan yang di hadapi dalam proses penjualan produk pakaian khususnya untuk penjualan ritel pada pelanggan Heyho Group Indonesia adalah:

a. Penggunaan internet pada toko Heyho Group Indonesia belum optimal sehingga, proses penjualan tersebut masih dilakukan secara konvensional.

b. Kurangnya struktur organisasi yang ada di Heyho Group Indonesia menyebabkan pelanggan yang telah membeli artikel produk kesulitan untuk melakukan retur dan terkadang penjual salah menulis harga yang ada dinota penjualan (human error) sehingga, sering kali perusahaan mengalami kerugian.

c. Dikarenakan kurangnya informasi penjualan sehingga, tidak diketahui produk yang terjual.

d. Dikarenakan sulitnya pelanggan jika ingin membeli produk yang mereka inginkan tidak ada toko Heyho Group Indonesia di daerahnya

Untuk menyelesaikan permasalahan di atas, maka sangat di perlukan suatu Metode berbasis website yang dapat menghasilkan informasi akurat dan efesien, mempermudah informasi promosi, tidak terbatas tempat dan waktu serta dapat mendukung secara penuh interaksi antara pelanggan dan Heyho Group Indonesia, Metode tersebut adalah rancangan e-commerce.

Rancangan e-commerce merupakan suatu rancangan sistem informasi penjualan yang berbasis online sehingga dapat memberikan informasi akurat dan efesien, memangkas biaya promosi, serta memiliki hubungan interaktif antara pelanggan dengan Heyho Group Indonesia.

\subsection{Ruang Lingkup}

Ruang lingkup atau batasan pada pembuatan analisa dan rancangan e-commerce pada Heyho Group Indonesia khusus untuk penjualan produk fashion secara ritel antara lain penginputan master produk, pendaftaran pelanggan, penginputan pemesanan, konfirmasi pesanan, pencetakan laporan pesanan, pencetakan laporan per produk dibeli, pencetakan laporan penjualan, pencetakan laporan user yang bertransaksi, dan pencetakan laporan kategori yang dibeli.

\subsection{Manfaat Penulisan}

a. Tujuan Penulisan

Tujuan dari penulisan penelitian ini adalah sebagai berikut :

1) Rancangan e-commerce untuk Heyho Group Indonesia adalah sebagai pengembangan sistem penjualan pada Heyho Group Indonesia, karena penjualan Heyho Group Indonesiasaat ini menurun, dengan dirancangnya sebuah e-commerce dapat membuat penjualan pada Heyho Group Indonesia meningkat.

2) Mempermudah dalam pencarian produk yang stoknya masih tersedia dan mencari produk yang akan dikirim kepada pelanggan.

3) Mempermudah dalam penyajian informasi yang dibutuhkan secara akurat dan tepat waktu serta dapat diakses dari mana saja baik pihak Heyho Group Indonesia maupun pelanggan.

4) Dengan adanya e-commerce ini, stok lama yang tidak terjual oleh toko Heyho Group Indonesia dapat ditampilkan informasinya kepada pelanggan pada bagian Halaman Depan, sehingga pelanggan dapat melihat dan tertarik membaca promosi yang disajikan oleh toko Heyho Group Indonesia melalui e-commerce.

b. Manfaat Penulisan

Manfaat dari penulisan penelitian ini diharapkan agar volume penjualan dapat meningkat, lebih mudah dalam mencari informasi produk dan jumlah pelanggan dapat meningkat.

\subsection{Batasan Masalah}

Untuk memperjelas cakupan permasalahan dalam penelitian ini maka penulis memberikan batasan masalah bahwa penelitian ini hanya terbatas tidak membahastentang fitur chat website untuk merancang dan membangun aplikasi yang di butuhkan oleh pelanggan dalam hal ini pemilik toko Heyho Group Indonesia dengan berdasarkan requirement aplikasi yang diberikan.

\section{STUDI PUSTAKA}

2.1. Konsep Dasar Sistem

a. Dasar Sistem Informasi

Menurut [1] Sistem Informasi adalah cara-cara yang diorganisasi untuk mengumpulkan, memasukkan, dan mengolah 
serta menyimpan data, dan cara-cara yang diorganisasi untuk menyimpan, mengelola, mengendalikan, dan melaporkan informasi sedemikian rupa sehingga sebuah organisasi dapat mencapai tujuan yang telah ditetapkan.

b. Pengertian Sistem

Sistem secara sederhana dapat di definisikan sebagai kelompok elemen yang saling berhubungan atau berinteraksi hingga membentuk satu persatuan. Konsep umum sistem adalah sekelompok komponen yang saling berhubungan, bekerja sama untuk mencapai tujuan bersama dengan menerima input serta menghasilkan output dalam process transformasi yang teratur[2]

\subsection{Pengertian Use Case}

Use case diagram merupakan pemodelan untuk kelakuan sistem informasi yang akan dibuat. Use case bekerja dengan mendeskripsikan tipikal interaksi antara user sebuah sistem dengan sistemnnya sendiri melalui sebuah cerita bagaimana sistem itu dipakai.[3]

\subsection{Digram UML}

Unified Modeling Languange (UML), Menurut [2] Unified Modelling Language (UML) adalah sebuah bahasa berdasarkan grafik atau gambar untuk memvisualisasi, menspesifikasikan, membangun dan pendokumentasian dari sebuah sistem pengembangan software berbasis $\mathrm{OO}$ (Object Oriented) UML tidak hanya merupakan sebuah bahasa pemrograman visual saja, namun juga dapat secara langsung dihubungkan ke berbagai bahasa seperti JAVA, C++, Visual Basic, atau bahkan dihubungkan secara langsung kedalam sebuah object-oriented database. Begitu juga mengenai pendokumentasian dapat dilakukan seperti requirement, arsitektur, desain, source code, project plain, tests, dan prototypes.

\subsection{Sequence Diagram}

Sequence diagram menggambarkan kelakuan objek pada use casedengan mendeskripsikan waktu hidup objek dan messageyang dikirimkan dan diterima antar objek.[4]

\subsection{Pengertian LRS}

Retur penjualan menurut [5] adalah Perusahaan mengembalikan / mengirim kembali barang yang dibeli kepada penjual dengan alasan tertentu.

\section{METODE PENELITIAN}

\subsection{Indentifikasi Masalah}

Dalam menemukan masalah penelitian, terlebih dahulu dilakukan kegiatan berfikir dan merenung guna memperoleh dan merenung guna memperoleh gagasan, ide dan motivasi untuk melakukan suatu penelitian.

\subsection{Metode Pengumpulan Data}

Adapun metode yang digunakan dalam pengumpulan data adalah sebagai berikut:

1. Observasi, Penulis melakukan pengamatan langsung terhadap proses bisnis yang sedang berjalan pada Heyho Group Indonesia.

2. Wawancara, Pengumpulan data dilakukan dengan cara bertatap muka langsung dengan mengajukan beberapa pertanyaanpertanyaan mengenai proses bisnis yang sedang berjalan kepada Karyawan Heyho Group Indonesia

\subsection{Teknik Analisa Data}

Untuk mempermudah proses penelitian dalam menganalisa masalah, masa dilakukan tahapantahapan analisa sistem sebagai berikut

1. Activity Diagram

Activity diagram digunakan untuk memodelkan alur kerja atau workflow sebuah proses bisnis dan urutan aktivitas didalam suatu proses.

2. Use Case Diagram

Use case diagram digunakan untuk menggambarkan interaksi antara pengguna sistem dengan kasus yang disesuaikan dengan langkah-langkah yang telah ditentukan.

3. Use Case Description

Use case Description digunakan untuk mendeskripsikan secara rinci mengenai use case diagram.

\subsection{Business Model Canvas (BMC)}

a. Key Partners

Key Partners Heyho Group Indonesia adalah suplier Brands yang menyediakan segala macam Item Brands yang ada di toko Heyho.

b. Key Activities

Key Activities Heyho Group Indonesia adalah penyedia beberapa Item Brands yang menyedikan Fashion untuk masyarakat, anak sekolah, dan mahasiswa.

c. Value Propositions

Value Propositions Heyho Group Indonesia adalah memberikan kemudahan dan mengenalkan produk-produk terbaru tentang parfum.

d. Customer Relationship

Customer Relationship Seruni parfum adalah sebagai berikut : 
1) Transactional : bisa beli langsung datang ke toko maupun media sosial dan WebSiteyang sudah disediakan.

2) Long-term : menjalin hubungan kepada reseller-reseller toko Brands lain dengan cara memberikan harga sesuai bagi para reseller tersebut.

e. Customer Segments

Customer Segments Heyho Group Indonesia sebagai berikut :

1) Kalangan Mahasiswa.

2) Komunitas Fashion Brand Local.

3) Anak Muda.

f. Key Resources

Key Resources sebagai berikut :

1) Tenaga yang meliputi : karyawan, kurir, Admin Media Sosial

2) Alat yang meliputi : komputer, smartphone.

g. Channel

Channel Heyho Group Indonesia adalah menggunakan sosial media seperti Instagram untuk mempopulerkan toko Heyho.

h. Cost Structure

Cost Structure Heyho Group Indonesia adalah biaya gaji karyawan, internet, Konveksi, Desainer.

i. Revenue Stream

Revenue Stream dari Heyho Group Indonesia adalah keuntungan dari hasil penjualan produk dan titipan barang yang di toko maupun di Online Shop dan WebSie Heyho Group Indonesia

\section{HASIL DAN PEMBAHASAN}

\subsection{Analisa Sistem}

Analisa sistem menggunakan Business Model Canvas

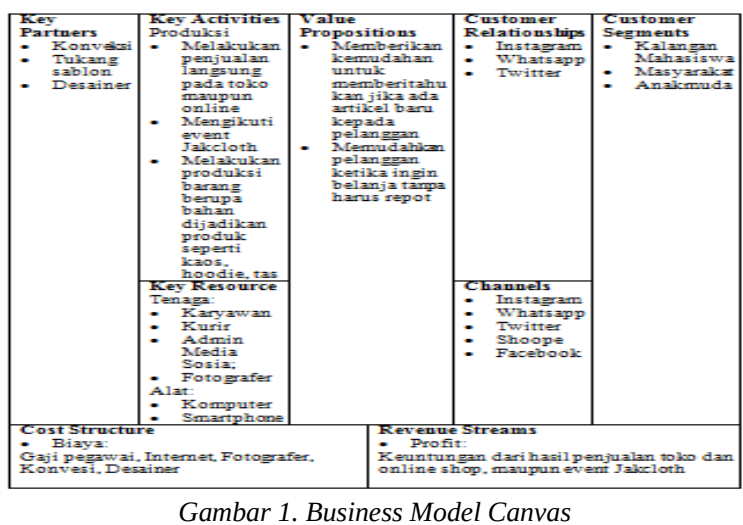

a. Key Partners

Key Partners Heyho Group Indonesia adalah suplier Brands yang menyediakan segala macam Item Brands yang ada di toko Heyho.

b. Key Activities
Key Activities Heyho Group Indonesia adalah penyedia beberapa Item Brands yang menyedikan Fashion untuk masyarakat, anak sekolah, dan mahasiswa.

c. Value Propositions

Value Propositions Heyho Group Indonesia adalah memberikan kemudahan dan mengenalkan produk-produk terbaru tentang Fashion Heyho Group Indonesia.

d. Customer Relationship

Customer Relationship Heyho Group Indonesia adalah sebagai berikut :

1) Transactional: bisa beli langsung datang ke toko maupun media sosial dan WebSite yang sudah disediakan.

2) Long-term: menjalin hubungan kepada reseller-reseller toko Brands lain dengan cara memberikan harga sesuai bagi para reseller tersebut.

e. Customer Segments

Customer Segments sebagai berikut :

1) Kalangan Mahasiswa.

2) Komunitas Fashion Brand Local.

3) Anak Muda.

f. Key Resources

Key Resources sebagai berikut :

1) Tenaga yang meliputi: karyawan, kurir, Admin Media Sosial

2) Alat yang meliputi: komputer, smartphone.

g. Channel

Channel Heyho Group Indonesia adalah menggunakan sosial media seperti Instagram untuk mempopulerkan toko Heyho Group Indonesia.

h. Cost Structure

Cost Structure Heyho Group Indonesia adalah biaya gaji karyawan, internet, Konveksi, Desainer.

i. Revenue Stream

Revenue Stream dari Heyho Group Indonesia adalah keuntungan dari hasil penjualan produk dan titipan barang yang di toko maupun di Online Shop dan WebSie Heyho Group Indonesia

\subsection{Activity Diagram}

a. Activity Diagram Berjalan

1. Proses Pembelian Produk Melalui Toko

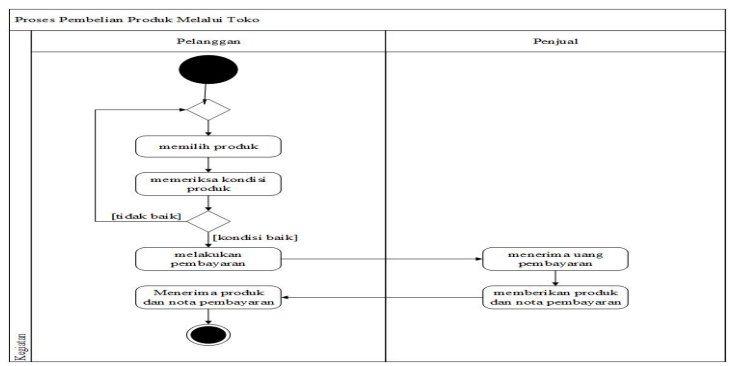

Gambar 2. Activity Diagram Pembelian Produk Melalui Toko 
Pelanggan datang langsung ke toko, pelanggan memilih produk, pelanggan mengecek kondisi produk, jika kondisi produk tidak baik maka pelanggan melakukan pemilihan produk kembali, jika kondisi produk baik pelanggan melakukan pembayaran, penjual menerima uang, kemudian penjual memberika produk kepada pelanggan, dan pelanggan menerima produk serta nota pembelian. Dapat dilihat pada gambar 2.

2. Proses Pembelian Produk Melalui Chat

Pelanggan meminta produk, lalu penjual memberikan beberapa foto produk, kemudian pelanggan memilih produk dan menyetujui produk, lalu penjual memberikan jumlah pembayaran serta nomor rekening bank, setelah itu pelanggan melakukan pembayaran via transfer, selanjutnya pelanggan memberikan bukti pembayaran, penjual mengecek bukti pembayaran, jika bukti pembayaran tidak valid dan uang tidak masuk, pelanggan di anjurkan untuk melakukan pembayaran ulang, namun jika bukti pembayaran valid dan uang masuk, pelanggan langsung diminta mengirimkan alamat tujuan pengiriman, lalu penjual melakukan pengiriman produk dan memberikan bukti pengiriman produk kepada pelanggan, pelanggan menerima bukti pengiriman, pelanggan menunggu produk sampai, dan pelanggan menerima produk serta nota pembelian Dapat dilihat pada gambar 3

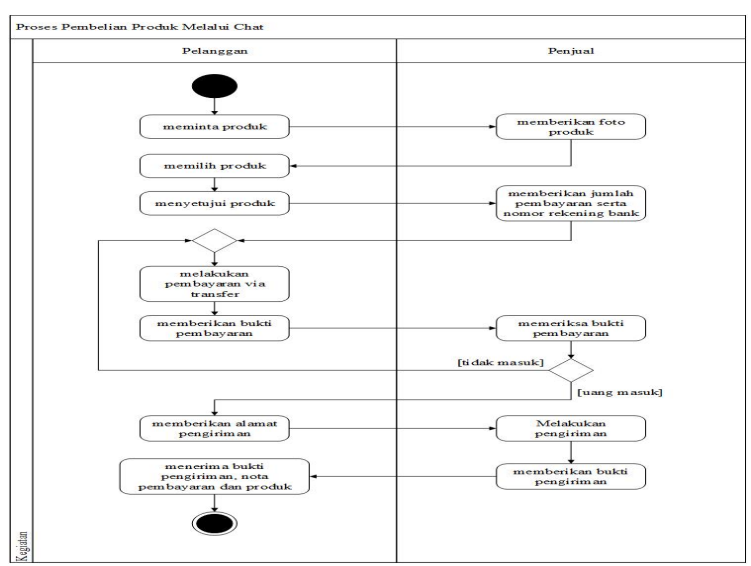

Gambar 3. Activity Diagram Pembelian Produk Melalui Chat

\section{Proses Retur Produk}

Pelanggan melakukan pengecekan produk, lalu pelanggan mendapatkan produk yang cacat atau tidak sesuai, pelanggan bisa melakukan pengembalian barang dengan datang langsung ke toko dan mengembalikan produk atau dikirim ulang melalui paket pengiriman, setelah itu penjual menerima produk, selanjutnya penjual mengecek apakah ada produk lain yang tersedia, jika ada maka penjual akan memberikan atau mengirimkan produk baru dan pelanggan menerima produk baru, namun jika tidak penjual akan mengembalikan jumlah uang yang sebelumnya telah dibayarkan pelanggan dan pelanggan menerima uang tersebut.

\subsection{Use Case Diagram}

\section{Use Case Package Diagram}

Dapat dilihat pada gambar 4 proses pada package diagram main terdapat 7 package, yaitu use case package akun, use case package master, use case package pesanan, use case package pembayaran, use case package pengiriman, use case package retur, dan use case package laporan.

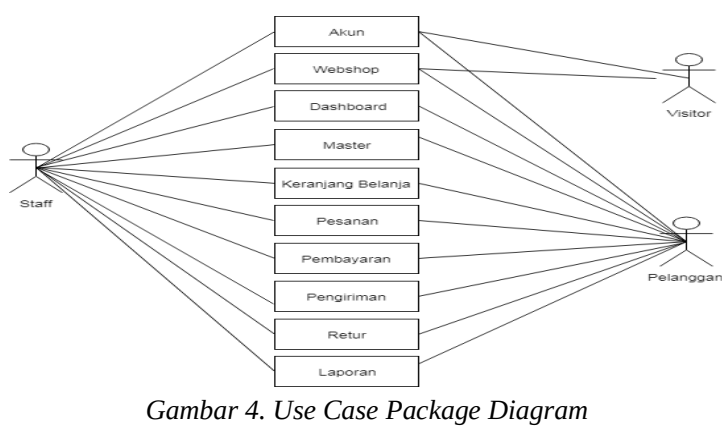

2. Use Case Package Akun

Dapat dilihat pada gambar 5 bahwa proses pada package diagram main terdapat 4 package, yaitu use case package registrasi, use case package login, use case package kelola profil, use case package logout.

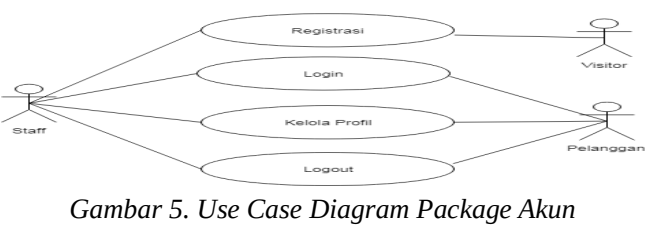

3. Use Case Diagram Webshop

Dapat dilihat pada gambar 6 bahwa proses pada use case diagram package webshop terdapat use case package cari produk, use case package lihat detil produk, use case package lihat histori pesanan dan lihat histori retur.

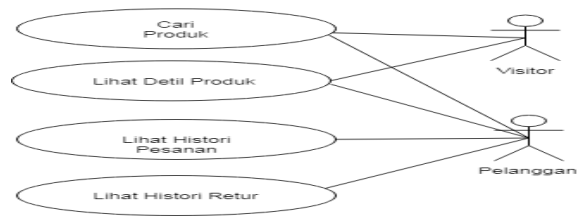

Gambar 6. Use Case Diagram Package Webshop

\section{Use Case Diagram Dashboard}

Dapat dilihat pada gambar 7 proses pada use case diagram package dashboard terdapat use case package kelola pesanan dan use case package kelola retur. 


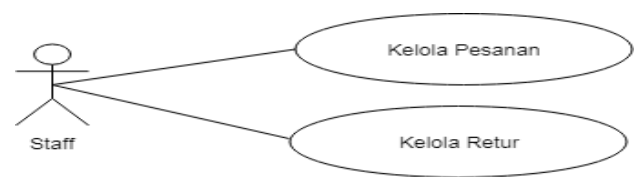

Gambar 7. Use Case Diagram Package Dashboard

5. Use Case Package Diagram Master

Dapat dilihat pada gambar 8 bahwa proses pada use case diagram package master terdapat use case package kelolabrand, use case package kelola dukungan pengiriman, use case package kelola ongkos kirim, use case package kelola bank, use case package kelola pelanggan dan use case package entri produk.

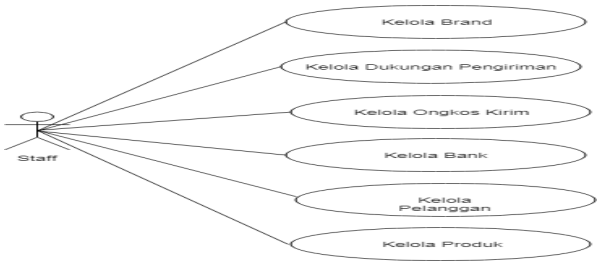

Gambar 8. Use Case Diagram Package Master

6. Use Case Diagram Pembayaran

Dapat dilihat pada gambar 9 bahwa proses pada use case diagram package master terdapat use case package kelolabrand, use case package kelola dukungan pengiriman, use case package kelola ongkos kirim, use case package kelola bank, use case package kelola pelanggan dan use case package entri produk.

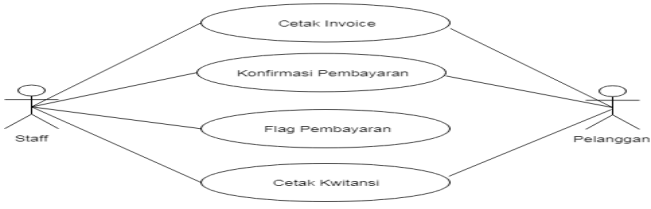

Gambar 9. Use Case Diagram Package Pembayaran

\subsection{Class Diagram Tanpa Method}

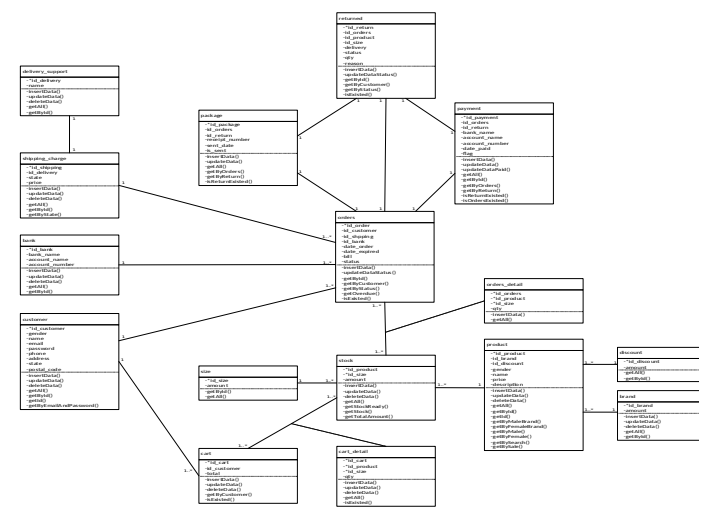

Gambar 10. Class Diaaram Tanna Method.
4.5. Struktur Menu

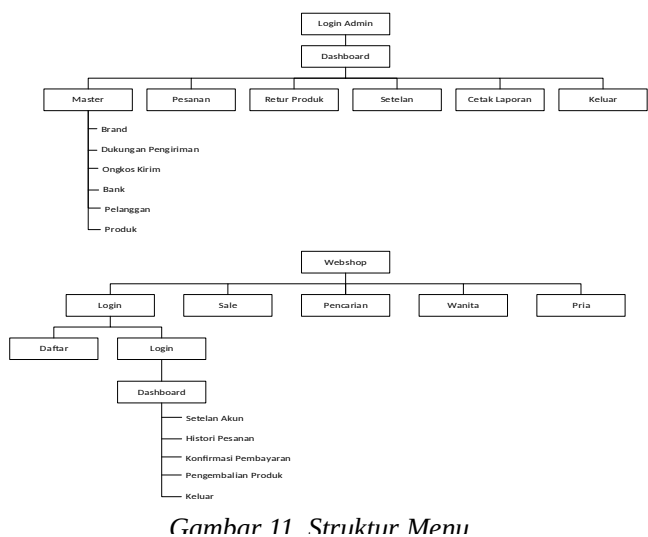

4.6. Rancangan Layar

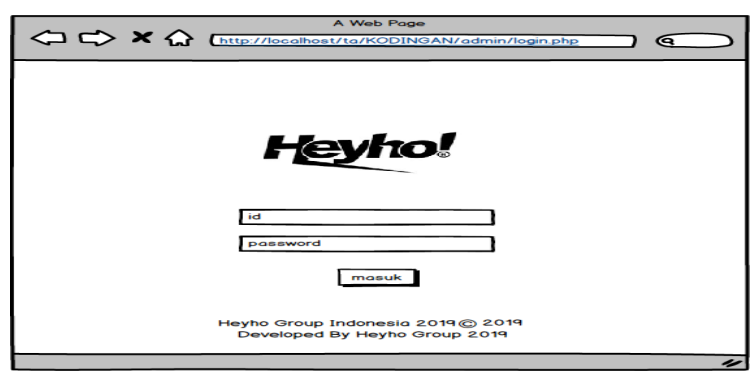

Gambar 12. Rancangan Layar Login Admin

Deskripsi rancangan layar gambar 12:

Pada rancangan layar ini staff dapat login dengan mengisi 2 textfield yaitu textfieldemail dan password. Lalu staff bisa langsung mengklik tombol MASUK.

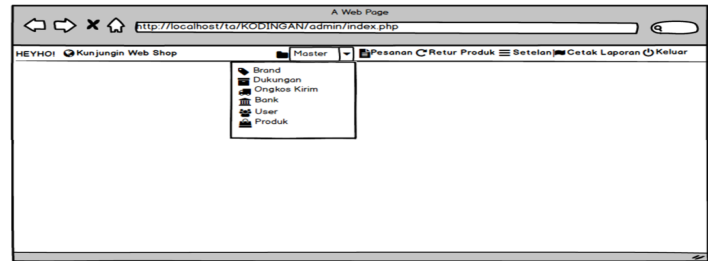

Gambar 13. Rancangan Layar Layar Home.

Deskripsi rancangan layar gambar 13:

a) Pada rancangan layar ini terdapat 7 menu utama yaitu Kunjungi Web Shop, Master, Pesanan, Retur Produk, Setelan, Cetak Laporan dan Keluar. Serta terdapat 6 sub menu pada Master yaitu Brand, Dukungan Pengiriman, Ongkos Kirim, Bank, Pelanggan dan Produk.

b) Menu Kunjungi Web Shop digunakan untuk mengunjungi website penjualan.

c) Menu Pesanan digunakan untuk mengelola pesanan produk. 
d) Menu Retur Produk digunakan untuk mengelola pesanan retur produk.

e) Menu Setelan digunakan untuk mengelola profil staff.

f) Menu Cetak Laporan digunakan untuk mencetak laporan-laporan.

g) Menu Keluar digunakan untuk logout dari home

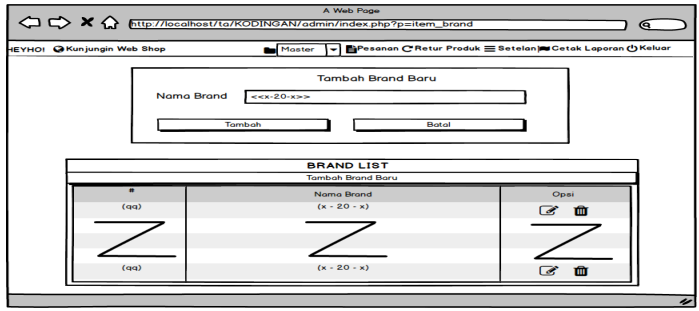

Gambar 14. Rancangan Layar Kelola Brand.

Deskripsi rancangan layar gambar 14:

a) Pada rancangan layar ini form data brand dan tabel list data brand.

b) Tabel list data brand berisikan brand brand yang sebelumnya sudah tersimpan pada sistem. Pada tabel ini disediakan 2 ikon disebelah kanan yang berfungsikan untuk mengubah data brand atau menghapus data brand.

c) Form data brand digunakan untuk menambah/mengubah data brand dengan mengisikan textfield nama brand lalu mengklik tombol tambah

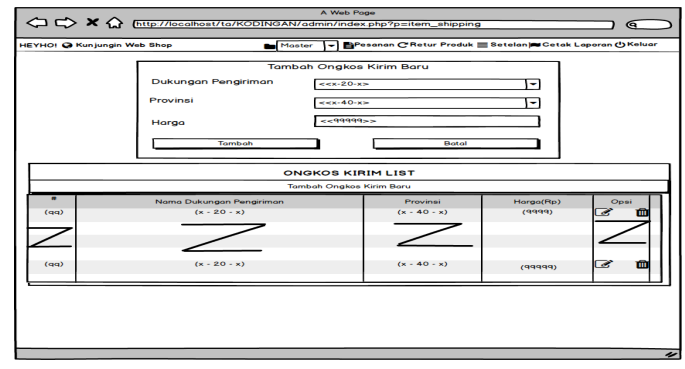

Gambar 15. Rancangan Layar Kelola Ongkos Kirim.

Deskripsi rancangan layar gambar 15 :

a) Pada rancangan layar ini form data ongkos kirim dan tabel list data ongkos kirim.

b) Tabel list data ongkos kirim berisikan ongkos kirim ongkos kirim yang sebelumnya sudah tersimpan pada sistem. Pada tabel ini disediakan 2 ikon disebelah kanan yang berfungsikan untuk mengubah data ongkos kirim atau menghapus data ongkos kirim.

c) Form data ongkos kirim digunakan untuk menambah/mengubah data ongkos kirim dengan memilih combobox nama dukungan pengiriman, memilih combobox provinsi dan mengisi textfield harga lalu mengklik tombol tambah.

\section{KESIMPULAN}

Setelah melakukan beberapa analisa dan membuat rancangan sistem, maka dapat diberikan beberapa kesimpulan dan saran sebagai bagian akhir atau penutup dari Laporan penelitian ini, yaitu:

a. Dengan adanya penerapan sistem ini semua transaksi pemesanan dan pembayaran lebih efisien dan data menjadi lebih akurat.

b. Dengan adanya fitur laporan stokproduk memudahkan penjual untuk mengetahui sisa produk yang telah terjual.

c. Dengan adanya fitur lapran pesanan memudahkan penjual untuk mengetahui seberapa banyak pesanan yang telah dipesan oleh pelanggan.

d. Dengan adanya fitur laporan pegiriman memudahkan penjual utnuk mengetahui jumlah pengriman yang dilakukan setiap harinya.

e. Dengan adanya fitur retur memudahkan pelanggan untuk melakukan pengembalian produk jika produk tersebut tidak sesuai dengan pesanan atau terdapat cacat pada produk tersebut.

f. Dengan adanya fitur laporan penjualan memudahkan penjual untuk mengetahui aktifitas apa saja yang terjadi.

\section{DAFTAR PUSTAKA}

[1] Krismiaji, Sistem Informasi Akuntansi, Unit Penerbit, Yogyakarta, 2015.

[2] Anggoro, D., Umar, M. D., Vinanty, E., Dananjaya, D., Informasi, F. T., Budi, U., ... Selatan, J. (2015). RANCANGAN SISTEM INFORMASI KOPERASI SIMPAN PINJAM GURU DAN PEGAWAI. Seminar Nasional Teknologi Informasi Dan Komunikasi 2015 (SENTIKA 2015) Yogyakarta, 28 Maret 2015 ISSN: 2089-9815, 2015(Sentika), 213222.

[3] Wira, D., Putra, T., \& Andriani, R. Unified Modelling Language ( UML ) dalam Perancangan Sistem Informasi Permohonan Pembayaran Restitusi SPPD. TEKNOIF, 7(1), 32-39, 2019.

[4] Alfarisy, M. H., \& Diana, A. Rancang Bangun Sistem Informasi Penyewaan Mobil pada Abu Sulaiman Rent Car. Seminar Rekayasa Teknologi Semrestek, 320-329, 2018.

[5] Ramdhany, T., \& Krisdiawan, R. A. APLIKASI SISTEM INFORMASI AKUNTASI PEMBELIAN KREDIT (STUDI KASUS: PT BERSAMA CIPTA RASA MULYA). Cload Information, 3(2), 2018. 